\title{
The impacts of climate, land use, and demography on fires during the 21st century simulated by CLM-CN
}

\author{
S. Kloster ${ }^{1}$, N. M. Mahowald ${ }^{2}$, J. T. Randerson ${ }^{3}$, and P. J. Lawrence ${ }^{4}$ \\ ${ }^{1}$ Land in the Earth System, Max Planck Institute for Meteorology, Hamburg, Germany \\ ${ }^{2}$ Earth and Atmospheric Sciences, Cornell University, Ithaca, NY, USA \\ ${ }^{3}$ Department of Earth System Science, University of California, Irvine, CA, USA \\ ${ }^{4}$ National Center for Atmospheric Research, Boulder, CO, USA \\ Correspondence to: S. Kloster (silvia.kloster@zmaw.de)
}

Received: 15 August 2011 - Published in Biogeosciences Discuss.: 28 September 2011 Revised: 20 December 2011 - Accepted: 3 January 2012 - Published: 26 January 2012

\begin{abstract}
Landscape fires during the 21st century are expected to change in response to multiple agents of global change. Important controlling factors include climate controls on the length and intensity of the fire season, fuel availability, and fire management, which are already anthropogenically perturbed today and are predicted to change further in the future. An improved understanding of future fires will contribute to an improved ability to project future anthropogenic climate change, as changes in fire activity will in turn impact climate.
\end{abstract}

In the present study we used a coupled-carbon-fire model to investigate how changes in climate, demography, and land use may alter fire emissions. We used climate projections following the SRES A1B scenario from two different climate models (ECHAM5/MPI-OM and CCSM) and changes in population. Land use and harvest rates were prescribed according to the RCP 45 scenario. In response to the combined effect of all these drivers, our model estimated, depending on our choice of climate projection, an increase in future (20752099) fire carbon emissions by 17 and $62 \%$ compared to present day (1985-2009). The largest increase in fire emissions was predicted for Southern Hemisphere South America for both climate projections. For Northern Hemisphere Africa, a region that contributed significantly to the global total fire carbon emissions, the response varied between a decrease and an increase depending on the climate projection.

We disentangled the contribution of the single forcing factors to the overall response by conducting an additional set of simulations in which each factor was individually held constant at pre-industrial levels. The two different projections of future climate change evaluated in this study led to increases in global fire carbon emissions by $22 \%$ (CCSM) and $66 \%$
(ECHAM5/MPI-OM). The RCP 45 projection of harvest and land use led to a decrease in fire carbon emissions by $-5 \%$. The RCP 26 and RCP 60 harvest and landuse projections caused decreases around $-20 \%$. Changes in human ignition led to an increase of $20 \%$. When we also included changes in fire management efforts to suppress fires in densely populated areas, global fire carbon emission decreased by $-6 \%$ in response to changes in population density.

We concluded from this study that changes in fire emissions in the future are controlled by multiple interacting factors. Although changes in climate led to an increase in future fire emissions this could be globally counterbalanced by coupled changes in land use, harvest, and demography.

\section{Introduction}

Contemporary landscape fires emit about 1.6 to $2.8 \mathrm{Pg} \mathrm{C} \mathrm{yr}^{-1}$ into the atmosphere (van der Werf et al., 2010). This equals around $20-30 \%$ of present day fossil fuel burning emissions (Boden et al., 2009). Changes in fires and subsequent changes in ecosystem carbon stocks can therefore have considerable impacts on atmospheric greenhouse gas concentrations and future climate change. In addition, increases in fires represent a severe hazard to human health and ecosystem services, which in many areas will require the development and implementation of new adaptation strategies (Bowman et al., 2009).

From paleorecords we know that climate, and particularly rapid climate change, plays an important role in determining fire activity (Marlon et al., 2009). Observations from more recent decades clearly show a link between changing climate 
and fire activity (Soja et al., 2007). For example, in the western United States higher temperatures increased the duration and intensity of wildfires since the 1980s (Westerling et al., 2006). Human-induced climate change has had a detectable influence on the area burned by forest fire in Canada over recent decades (Gillett et al., 2004). Accelerated carbon losses for the last several decades were reported for Alaskan forests and peatlands (Turetsky et al., 2011).

Fires depend on fuel type, fuel moisture, and fuel availability. In addition, fires require an ignition source which can be either of natural (lightning) or anthropogenic origin (Thonicke et al., 2001; Arora and Boer, 2005). Climate impacts fires directly by modulating fuel moisture and indirectly through the climate control of fuel availability (Flannigan et al., 2009). Fuel availability, for example, depends on the rate of plant growth and litter decomposition that are sensitive to climate change. Fuel availability is controlled by fire as well, which consumes biomass and lowers fuel loads. As such fires and fuel availability are coupled via a negative feedback loop that is likely to influence the way fires will change in the future.

Fires are directly anthropogenically controlled through human caused ignition and fire management efforts, set in place to suppress fires in places where properties are at risk (Bowman et al., 2009). Land use and wood harvest rates impact fires indirectly by controlling fuel loads and fuel connectivity (Marlon et al., 2009). Consequently, fires depend on social and economic drivers of land use and on demographic trends.

Here we investigated how fires may change during the 21 st century. We used a global land carbon model that interactively simulated landscape fires, with fires responding to climate, land use and demographic driving variables. The model accounted for fires controlled by fuel moisture, fuel availability, and the abundance of ignition sources (Kloster et al., 2010). We examined how future changes in climate, land use, and demography were likely to influence trajectories of fire emissions during the 21 st century. We also considered indirect controls, including for example climate-induced changes in fuel. In the following method section we will introduce the fire model that was evaluated for the 20th century in an earlier work (Kloster et al., 2010) and our simulation design. In the results section we discuss the simulated future fire emissions and the contribution of the single forcing factors (climate, land use, and demography) to the overall response. The conclusion section summarizes the results and discusses the limitations of our approach.

\section{Model}

All simulations in this study were performed with a modified version of the Community Land Model version 3.5 (CLM3.5; Oleson et al., 2008; Stoeckli et al., 2008) extended with a carbon-nitrogen biogeochemical model (Thornton et al., 2007, 2009; Randerson et al., 2009) hereafter referred to as
CLM-CN. The modifications of the model physics beyond CLM3.5 incorporate most of the updates of the model that now make up CLM version 4 (Lawrence et al., 2011b) and were described in more detail previously by Kloster et al. (2010).

Fires were represented in the model by a modified version of the fire algorithm developed by Arora and Boer (2005). This fire algorithm was implemented into CLM-CN to simulate landscape fires for the 20th century and was described and evaluated in detail in Kloster et al. (2010). We briefly describe the fire algorithm here.

Fire carbon emissions (FCE) to the atmosphere were parameterized following a modified Seiler and Crutzen (1980) approach (van der Werf et al., 2006):

$\operatorname{FCE}(x, t)=A(x, t) \sum C_{i}(x, t) \cdot \operatorname{cc}_{i}(x, t) \cdot \operatorname{mort}_{i}(x, t)$

with $A$ representing the area burned, $C$ the carbon pool sizes for the different fuel and plant functional types $(i)$ considered in CLM-CN, "cc" the combustion completeness, and "mort" the mortality factor for any given location $x$ and time $t$. "cc" and "mort" varied for different fuel and plant functional types (i) within CLM-CN.

The burned area was parameterized in the fire algorithm as a function of a potential burned area modified with a fire occurrence probability (Arora and Boer, 2005). The potential burned area was defined by the fire spread rate, which was parameterized as a function of wind speed and fuel moisture. The fire occurrence probability was the product of three probability functions representing the availability of biomass, fuel moisture status, and the likelihood of the ignition. Ignition sources can have either a human or lightning origin. A lightning climatology was constructed using monthly mean maps from the Lightning Imaging Sensor/Optical Transient Detector product (LIS/OTD) modified by a latitudinally varying ratio of the cloud-to-ground flashes to total flashes (Pierce, 1969). Human ignition probability was accounted for following a relationship given by Venevsky et al. (2002), which assumes that an average person is more likely to cause a fire in sparsely populated regions, as they interact more with the natural ecosystems, compared to persons living in densely populated areas. Densely populated areas were defined as areas exceeding 300 inhabitants $\mathrm{km}^{-2}$ on grid box average. In addition the model accounted for fire management (e.g. fire suppression). Fire suppression will more likely take place in densely populated areas where typically high property values are at risk compared to sparsely populated areas (Stocks et al., 2003; Theobald and Romme, 2007). We parametrized fire suppression similar to Pechony and Shindell (2009) as a function of the population density ("popd" in inhabitants $\mathrm{km}^{-2}$ )

$F_{\text {supp }}=1 .-(0.1+\exp (0.025 \cdot$ popd $))$

assuming that in densely populated areas $90 \%$ of the fires will be suppressed. 
The burned area was assumed to affect the different PFTs in proportion to their abundance. This assumption may not be appropriate for all landscapes and may impact simulated fire carbon emissions significantly as for example herbaceous and woody fuels differ by an order of magnitude (van der Werf et al., 2010).

The model represented deforestation fires by allowing for a variable fraction of deforestation carbon to be combusted, with the fraction depending on fuel conditions during the year of land clearing (Kloster et al., 2010). Within CLM$\mathrm{CN}$ land use change and wood harvest were prescribed (Hurtt et al., 2006). Land use conversion transferred biomass into paper and wood products with the remainder left on site (Houghton et al., 1983, see also Lawrence et al., 2011a, for the details on land use change implementation in CLM-CN). To account for deforestation fires we explicitly attributed a fraction of the biomass left on site to burning. We allowed this fraction to vary with fuel moisture conditions, with drier fuels more likely to be burned in the process of deforestation. In the model this fraction was expressed by the simulated fire moisture probability:

$$
\begin{aligned}
\text { frac }= & \operatorname{frac}_{\min }+\left(\operatorname { m a x } \left[0, \min \left(1, P_{\mathrm{ml}}-P_{\mathrm{ml} \_ \text {low }}\right) /\left(P_{\mathrm{ml} \_ \text {high }}\right.\right.\right. \\
& \left.\left.\left.-P_{\mathrm{ml} \_ \text {low }}\right)\right]\right) \cdot\left(\operatorname{frac}_{\max }-\mathrm{frac}_{\min }\right)
\end{aligned}
$$

where $P_{\mathrm{ml}}$ equals the fire moisture probability, $\operatorname{frac}_{\min }$ and frac $_{\max }$ are the minimum and maximum fraction set to 0.2 and 0.8 , respectively, and $P_{\mathrm{ml} \_ \text {low }}$ and $P_{\mathrm{ml} \text { high }}$ are the low and high thresholds for the moisture fire probability set to 0.01 and 0.30 , respectively (see also Kloster et al., 2010).

Our model simulations have a spatial resolution of $1.9^{\circ} \times 2.5^{\circ}$. More details on the forcing data are given in Sect. 3 .

The model was able to capture much of the observed mean and variability in fire carbon emissions (Kloster et al., 2010). Global annual mean fire carbon emissions varied between 2.0 and 2.4 $\mathrm{Pg} \mathrm{C} \mathrm{yr}^{-1}$ for the time period 1997 to 2004, which lies within the uncertainty of satellite-based estimates. The best match with observations was found when the model accounted for both human ignition and fire suppression as a function of population density. The simulated trend in fire carbon emission over the 20th century was broadly consistent with observational constraints.

\section{Simulation setup}

In the present study we analyzed CLM-CN simulations covering the time period 1798-2100 (Table 1). For the years 1798-2004 these simulations are described in detail in Kloster et al. (2010). As described below, we extended these simulations through the year 2100 .

For the 20th century we used NCEP/NCAR reanalysis climate forcing, including temperature, precipitation, wind, humidity, pressure, and solar radiation, from Qian et al. (2006). A $25 \mathrm{yr}$ repeat cycle of the reanalysis from years a

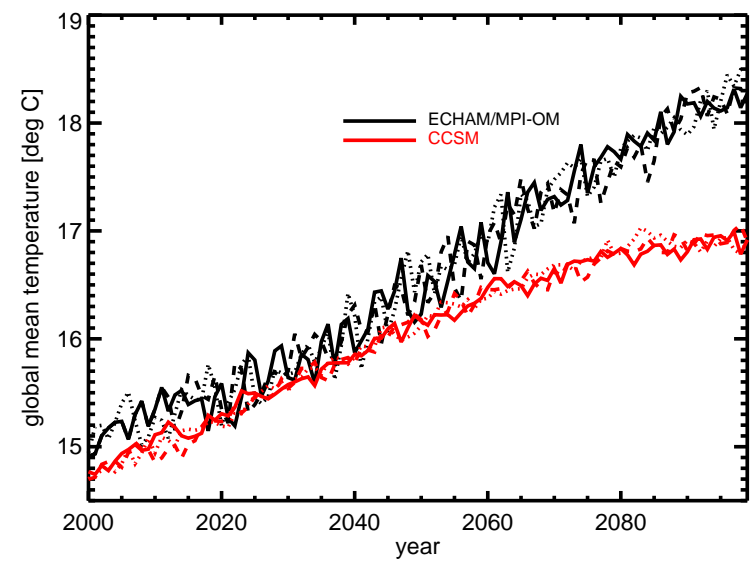

$\mathrm{b}$

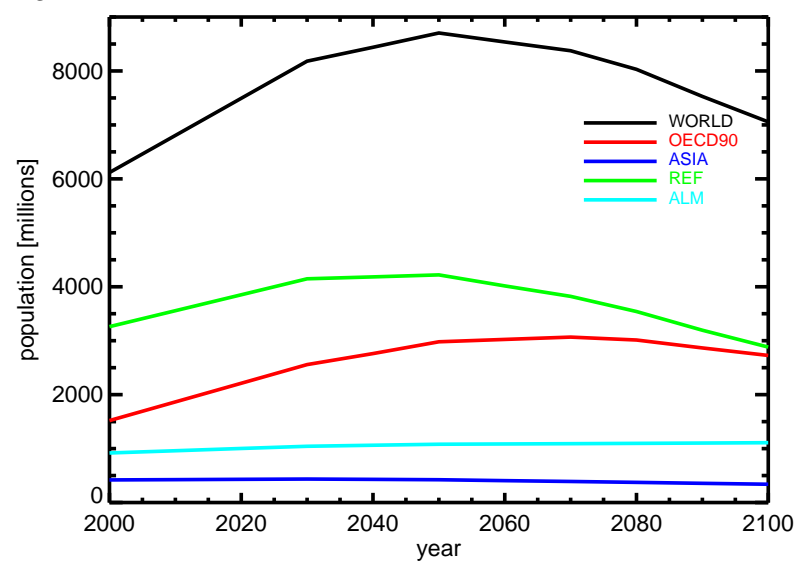

C

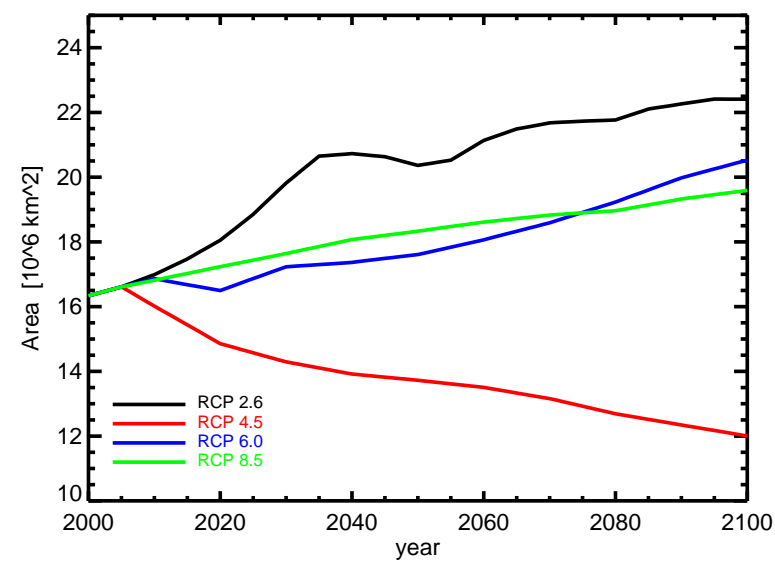

Fig. 1. Forcing factors applied in this study. (a) Climate - global annual mean surface temperature in [deg C] as simulated with ECHAM/MPI-OM (Roeckner et al., 2006) and CCSM (Meehl et al., 2006). Both models applied the IPCC A1B SRES scenario forcing (Nakicenovic et al., 2000). For each model three ensemble simulations are shown. (b) Population - total population for the IPCC A1B SRES scenario for the SRES regions and the global total (CIESIN, 2002). (c) Land use change - global total crop area for the different RCPs. 
Table 1. Control and transient model simulations analyzed in the present study. Simulations used different treatment of human ignition potential, and different assumptions about harvest/land cover change as well as climate forcing.

\begin{tabular}{|c|c|c|c|c|}
\hline Name & $\begin{array}{c}\text { Human ignition } \\
\text { probability }\end{array}$ & Pop. density ${ }^{b}$ & $\begin{array}{l}\text { harvest/land } \\
\text { cover change }^{c}\end{array}$ & $\begin{array}{l}\text { Climate forcing } \\
\text { future }\end{array}$ \\
\hline \multicolumn{5}{|c|}{ Transient simulations: $1798-2100$} \\
\hline AB-26-E1 & constant $=0.5$ & - & RCP 26 & ECHAM 1 \\
\hline $\mathrm{AB}-45-\mathrm{E} 1$ & constant $=0.5$ & - & $\mathrm{RCP} 45$ & ECHAM 1 \\
\hline $\mathrm{AB}-45-\mathrm{C} 1$ & constant $=0.5$ & - & $\mathrm{RCP} 45$ & CCSM 1 \\
\hline AB-60-E1 & constant $=0.5$ & - & RCP 60 & ECHAM 1 \\
\hline AB-85-E1 & constant $=0.5$ & - & RCP 85 & ECHAM 1 \\
\hline AB-HI-45-E1 & human ignition & transient & $\mathrm{RCP} 45$ & ECHAM 1 \\
\hline AB-HI-FS-45-E1/2/3 & human ign. and fire suppr. & transient & $\mathrm{RCP} 45$ & ECHAM 1/2/3 \\
\hline AB-HI-FS-45-C1/2/3 & human ign. and fire suppr. & transient & $\mathrm{RCP} 45$ & $\operatorname{CCSM} 1 / 2 / 3$ \\
\hline \multicolumn{5}{|c|}{ Sensitivity simulations: $1798-2100$} \\
\hline AB-LUC-E1 & constant $=0.5$ & - & - & ECHAM 1 \\
\hline AB-45-CLIM & constant $=0.5$ & - & $\mathrm{RCP} 45$ & NCEP/NCAR \\
\hline AB-HI-PI-45-E1 & human ignition & preindustrial & $\mathrm{RCP} 45$ & ECHAM 1 \\
\hline AB-HI-FS-PI-45-E1 & human ign. and fire suppr. & preindustrial & $\mathrm{RCP} 45$ & ECHAM 1 \\
\hline
\end{tabular}

\footnotetext{
a Different treatment of human ignition probability: either a constant value of 0.5 , allowing for human ignition as a function of population density (HI), or human ignition and fire suppression (HI-FS).

b Population density was allowed to vary between 1798 and 2100 (for 1798 to 2004 following Klein Goldewijk (2001), from 2005 onwards scaled with the SRES A1 projections for the SRES world regions (CIESIN, 2002)) or was held constant at a preindustrial value.

${ }^{c}$ Harvest/land cover change: either no harvest/land cover change (-) or transient historical harvest/land cover change between 1850-2004 and between 2005-2100 projected harvest/land cover change following the RCP 26, 45, 60, and 85, respectively (Hurtt et al., 2006; Moss et al., 2010).

d Climate forcing: cycling periodically through NCEP/NCAR data (Qian et al., 2006) for the years 1948-1972. For future climate forcing (1973-2100) we scaled NCEP/NCAR forcing with future climate anomalies simulated by the climate model ECHAM/MPI-OM (Roeckner et al., 2006) or CCSM (Meehl et al., 2006) applying three different ensembles (1-3) each.
}

1948-1972 was used to drive the model for the time period of 1798-1948. From year 1949 onwards the model years corresponded to the reanalysis years. The simulations applied transient varying nitrogen deposition (Lamarque et al., 2005), atmospheric $\mathrm{CO}_{2}$ concentration (C4MIP reconstruction from Friedlingstein et al., 2006), population density (Klein Goldewijk, 2001), and harvest/land cover (Hurtt et al., 2006) change for the years 1798-2004.

We extended these simulations into the future by applying climate anomalies based on future climate projections of the coupled climate models ECHAM5/MPI-OM (Roeckner et al., 2006) and CCSM (Meehl et al., 2006), both forced with the SRES A1B scenario (Nakicenovic et al., 2000). Both climate model simulations cover the time period 1860 to 2100 . The climate models differ in their future projections. For example, the global mean temperature increases are stronger in the ECHAM5/MPI-OM projection compared to CCSM (Fig. 1a).

We defined climate anomalies as the mean difference between monthly mean future projections and a base period (1948-1972) for the climate models and applied these to the NCEP/NCAR reanalysis climate forcing (1948-1972) used to force the CLM-CN model. As a result CLM-CN was in this study forced from 1973 onwards with NCEP/NCAR reanalysis climate forcing scaled by climate anomalies. A sub- set of our simulations used three different ensemble climate model simulations from each climate model. The different ensembles led to very similar results for both climate model projections and will not be further discussed.

Future changes in population density followed the SRES A1 projections for the SRES world regions (CIESIN, 2002), in which global population increases up to the year 2050 and slightly declines afterwards (Fig. 1b). Future atmospheric $\mathrm{CO}_{2}$ concentration followed the SRES A1B projections, while nitrogen deposition remained at a present day level.

Future harvest/land cover change rates were prescribed following the Representative Concentration pathways (RCPs) projections 26, 45, 60, and 85 (Moss et al., 2010). The RCPs are named according to their radiative forcing level in 2100 , i.e. RCP 85 corresponds to a radiative forcing of $8.5 \mathrm{~W} \mathrm{~m}^{-2}$ in 2100 . Hurtt et al. (2006) developed the single RCP projections for land cover change with the global land model (GLM) in a way that they are seamlessly integrated with respect to past land cover change estimates through the year 2005 and contain the information needed to account for land use change explicitly in the model in terms of the impact on the carbon cycle. The land cover RCP projections for land use change were, however, not consistent with the projected climate used in this study, which was 


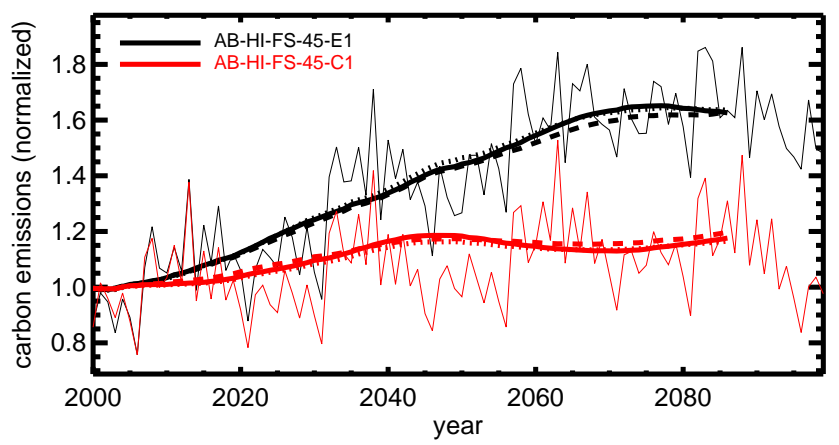

Fig. 2. Change in future global annual mean fire emissions normalized to the mean state 1990-2009 as simuated with two different climate forcings (ECHAM/MPI-OM (E1; Roeckner et al., 2006) or CCSM (C1; Meehl et al., 2006)) when human ignition (HI) and fire suppresion (FS) were taken into account and future LUC/Harvest followed RCP 45 . For each experiment three ensemble simulations are shown (see also Table 1 for a description of the experiments). The timeseries were smoothed with a $25 \mathrm{yr}$ running mean. In addition, for each experiment one ensemble is shown with a yearly time resolution (thin solid line).

based on the SRES scenario A1B. Climate projections consistent with the RCPs were not available at the time of this study. How the RCP land cover projections are represented in CLM-CN is described in detail in Lawrence et al. (2011a). An example of projected crop area in the different RCP projections is shown in Fig. 1c. These variations in land cover have important consequences for landscape and deforestation fires.

In sensitivity experiments single forcing factors (climate, population density, and harvest/land cover change) were individually held constant at preindustrial values throughout the simulation period (Table 1). We then took the difference between the primary simulation and the single forcing runs to isolate the contribution of a single factor to changes in fire emissions.

\section{Results}

We found that global fire emissions increased in response to combined changes in climate, land use change, and demography. Global annual mean fire carbon emissions from the simulation (AB-HI-FS, Table 1) for which we obtained the best match with contemporary observations (Kloster et al., 2010) are shown in Fig. 2. In these simulations both human ignition and fire suppression parameterization were derived from time series of population density (SRES A1B) and harvest and land use followed the RCP 45 projection. We forced the model with two different climate projections (ECHAM5/MPI-OM or CCSM, see also Table 1). Global annual mean future (2075-2099) fire emissions increased by $17 \%$ for CCSM and by $62 \%$ for ECHAM5/MPI-OM

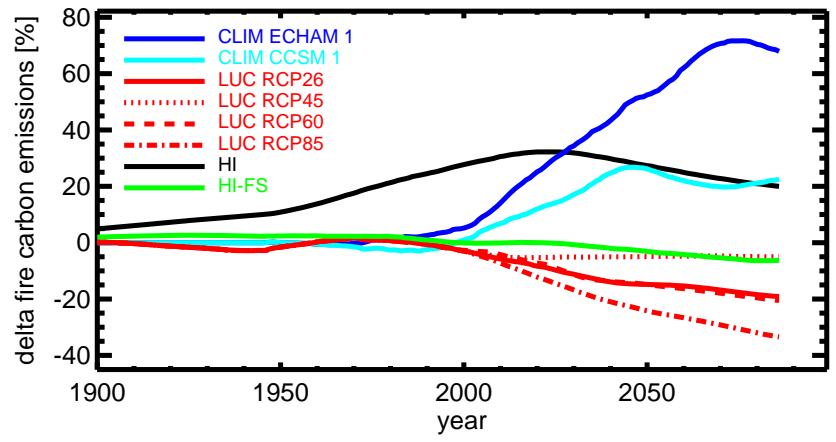

Fig. 3. Change in global annual mean fire emissions 1900 to 2100 in [\%] introduced by different forcings: climate: ECHAM/MPIOM (CLIM ECHAM 1, Roeckner et al., 2006) in blue and CCSM (CLIM CCSM 1, Meehl et al., 2006) in light blue, respectively; harvest/land use change in red for RCP 26, 45, 60, and 85, respectively; human ignition in black; human ignition and fire suppression in green. Simulations with transient varying forcings are compared to a control simulation in which the forcing is kept constant. The difference in percentage is calculated relative to the control simulation. The timeseries were smoothed with a $25 \mathrm{yr}$ running mean.

compared to present day (1985-2009). This corresponded to increases of 0.29 and $1.03 \mathrm{Pg} \mathrm{C} \mathrm{yr}^{-1}$, respectively. The largest increase in absolute terms for both climate projections occured in Southern Hemisphere South America (0.20 and $0.57 \mathrm{Tg} \mathrm{C} \mathrm{yr}^{-1}$, respectively).

Regionally we found strong differences in the response, as a result of combined changes in climate, land use change, and demography. To disentangle the simulated changes in future fire emissions caused by these different drivers we performed sensitivity simulations in which the drivers were kept constant individually at their preindustrial level. The results are summarized in Fig. 3 and Table 2. Globally, projected changes in climate led to an increase in fire carbon emissions in 2075-2099 compared to the preindustrial control $(+22 \%$ and $+66 \%$ for CCSM and ECHAM5/MPI-OM, respectively). Changes in population density led to an increase in fire emissions when only human ignition was taken into account by $+20 \%$. When changes in fire management efforts to suppress fires in densely populated areas also were included, fire carbon emissions decreased by $-6 \%$. Projected harvest and land use change led to a decrease in fire emissions, with the magnitude of the response depending on the RCP scenario applied $(-5$ to $-35 \%)$.

In the following sections we examine the simulated changes in future fire emissions attributable to different drivers (climate, population density, and harvest/land cover change) in more detail. 
Table 2. Changes in global annual mean fire emissions caused by different forcings agents averaged over the period 2075-2099 [Tg C yr ${ }^{-1}$ ]. Number in brackets are changes in percentage. Simulations with transient varying forcings were compared to a control simulation in which the forcing was kept constant at preindustrial level. The difference in percentage was calculated relative to the control simulation. Regions used in this study were identical to the one defined in van der Werf et al. (2006): BONA: Boreal North America, TENA: Temperate North America, CEAM: Central America, NHSA: Northern Hem. South America, SHSA: Southern Hem. South America, EURO: Europe, MIDE: Middle East, NHAF: Northern Hem. Africa, SHAF: Southern Hem. Africa, BOAS: Boreal Asia, CEAS: Central Asia, SEAS: South East Asia, EQAS: Equatorial Asia, AUST: Australia.

\begin{tabular}{|c|c|c|c|c|c|c|c|c|}
\hline & Climate $^{\mathrm{a}}$ & Climate $^{\mathrm{a}}$ & Harvest/LCC ${ }^{\mathrm{b}}$ & Harvest/LCC ${ }^{b}$ & Harvest/LCC ${ }^{\mathrm{b}}$ & Harvest/LCC ${ }^{b}$ & pop. density ${ }^{c}$ & pop. density ${ }^{\mathrm{c}}$ \\
\hline & ECHAM/MPI-OM & CCSM & $\mathrm{RCP} 26$ & $\mathrm{RCP} 45$ & RCP60 & RCP85 & HI & HI FS \\
\hline BONA & $23.0(256)$ & $27.0(300)$ & $-4.0(-13)$ & $0.0(0)$ & $-18.0(-56)$ & $-15.0(-47)$ & $7.0(39)$ & $2.0(12)$ \\
\hline TENA & $55.0(56)$ & $21.0(21)$ & $-34.0(-22)$ & $-1.0(-1)$ & $-57.0(-37)$ & $-57.0(-37)$ & $29.0(24)$ & $-22.0(-19)$ \\
\hline CEAM & $36.0(32)$ & $36.0(32)$ & $-41.0(-27)$ & $-3.0(-2)$ & $-45.0(-29)$ & $-77.0(-50)$ & $54.0(47)$ & $-20.0(-17)$ \\
\hline NHSA & $127.0(61)$ & $47.0(22)$ & $-14.0(-4)$ & $0.0(0)$ & $-17.0(-5)$ & $-42.0(-13)$ & $73.0(35)$ & $47.0(22)$ \\
\hline SHSA & $597.0(84)$ & $237.0(33)$ & $-134.0(-10)$ & $-20.0(-2)$ & $-130.0(-10)$ & $-293.0(-22)$ & $173.0(15)$ & $35.0(3)$ \\
\hline EURO & $53.0(166)$ & $33.0(103)$ & $-50.0(-54)$ & $-8.0(-9)$ & $-47.0(-51)$ & $-39.0(-42)$ & $7.0(9)$ & $-17.0(-29)$ \\
\hline MIDE & $2.0(13)$ & $1.0(7)$ & $-10.0(-53)$ & $-2.0(-11)$ & $-5.0(-26.3)$ & $-7.0(-37)$ & $3.0(20)$ & $-4.0(-29)$ \\
\hline NHAF & $156.0(72)$ & $-35.0(-16)$ & $-40.0(-33)$ & $-51.0(-12)$ & $-63.0(-15)$ & $-152.0(-36)$ & $62.0(19)$ & $-76.0(-23)$ \\
\hline SHAF & $121.0(35)$ & $10.0(3)$ & $-145.0(-29)$ & $-38.0(-8)$ & $-87.0(-17)$ & $-197.0(-39)$ & $88.0(21)$ & $-25.0(-6)$ \\
\hline BOAS & $39.0(650)$ & $33.0(550)$ & $-3.0(-7)$ & $-1.0(-2)$ & $-5.0(-11)$ & $-14.0(-30)$ & $2.0(6)$ & $-1.0(-3)$ \\
\hline CEAS & $182.0(200)$ & $73.0(85)$ & $-91.0(-28)$ & $-47.0(-15)$ & $-165.0(-52)$ & $-190.0(-59)$ & $33.0(15)$ & $-42.0(-24)$ \\
\hline SEAS & $82.0(36)$ & $15.0(7)$ & $-134.0(-37)$ & $-60.0(-16)$ & $-190.0(-52)$ & $-178.0(-49)$ & 49.0 (18) & $-78.0(-33)$ \\
\hline EQAS & $50.0(70)$ & $19.0(27)$ & $-14.0(-11)$ & $-3.0(-2)$ & $-67.0(-54)$ & $-70.0(-57)$ & $34.0(44)$ & $-4.0(-5)$ \\
\hline AUST & $23.0(30)$ & $6.0(8)$ & $-28.0(-29)$ & $3.0(3)$ & $-28.0(-29)$ & $-54.0(-55)$ & $19.0(26)$ & $10.0(14)$ \\
\hline GLOB & $1386.0(66)$ & $469.0(22)$ & $-769.0(-21)$ & $-199.0(-5)$ & $-822.0(-22)$ & $-1278.0(-35)$ & $591.0(20)$ & $-177.0(-6)$ \\
\hline
\end{tabular}

a Response to climate change: future climate anomalies simulated by the climate model ECHAM/MPI-OM (Roeckner et al., 2006) or CCSM (Meehl et al., 2006).

b Response to Harvest/land cover change: projected changes following the RCP 26, 45, 60, and 85, respectively (Hurtt et al., 2006; Moss et al., 2010).

${ }^{\mathrm{c}}$ Response to changes in population density: allowing for human ignition as a function of population density (HI), or human ignition and fire suppression (HI-FS).
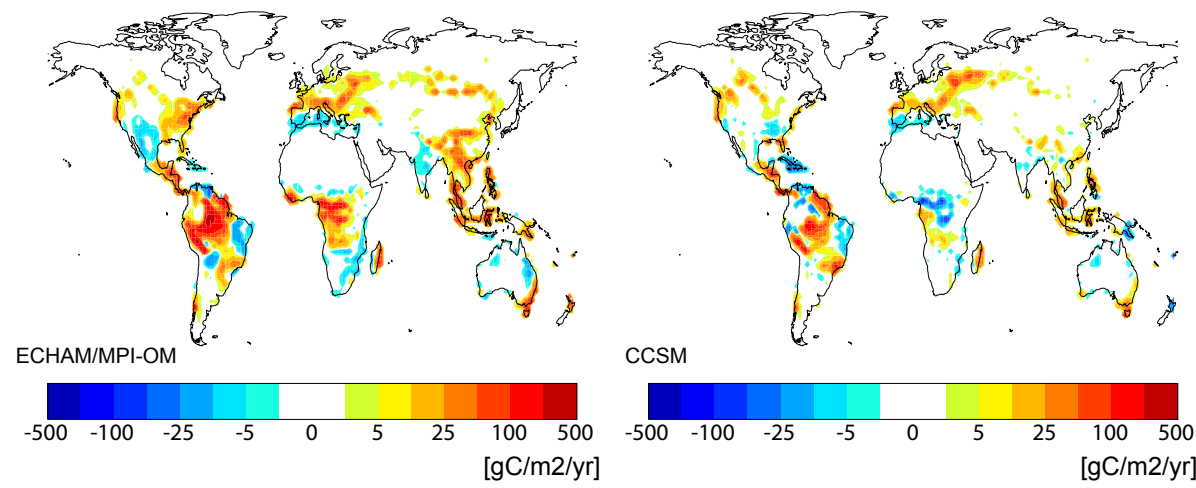

Fig. 4. Change in annual mean fire emissions in $\left[\mathrm{gC} /\left(\mathrm{m}^{2} \mathrm{yr}\right)\right]$ averaged over $2075-2099$ introduced by changes in climate. Simulations with transient varying forcings are compared to a control simulation in which the forcing is kept constant at preindustrial level. Left side: ECHAM/MPI-OM A1B (Roeckner et al., 2006) future climate forcing (AB-45-E1 minus AB-45-CLIM); Right side: CCSM A1B (Meehl et al., 2006) future climate forcing (AB-45-C1 minus AB-45-CLIM).

\subsection{Response of fire to future changes in climate}

Fire emissions respond to changes in climate via a range of factors, including changes in fuel moisture, fuel availability, and fire spread (e.g. Spracklen et al., 2009; Flannigan et al., 2009). Changes in fire emissions are closely connected to changes in the hydrological cycle. However, future projections of the hydrological cycle are very uncertain. While models show, for example, a consistent increase in globally averaged precipitation with global warming, they differ substantially in magnitude as well as in the spatial and seasonal distributions (Meehl et al., 2007). To partly account for this, we investigated the impact of changes in climate on fire emissions using output from two different coupled ocean-atmosphere models (CCSM and ECHAM5/MPI-OM) both forced with the IPCC SRES A1B scenario. 
a) temperature

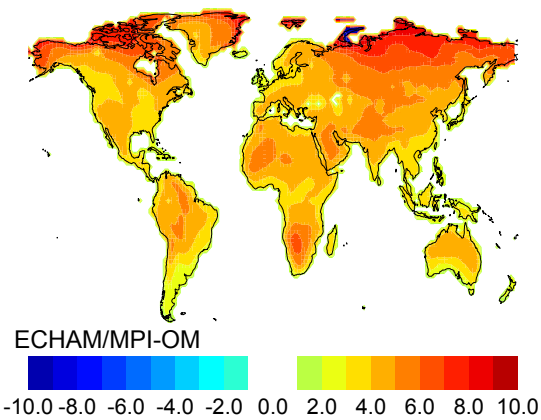

b) precipitation

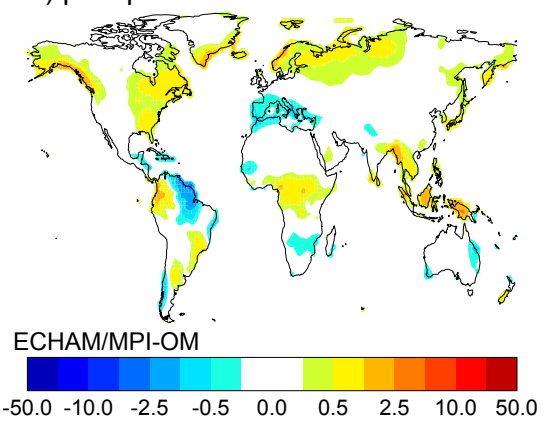

c) aboveground biomass

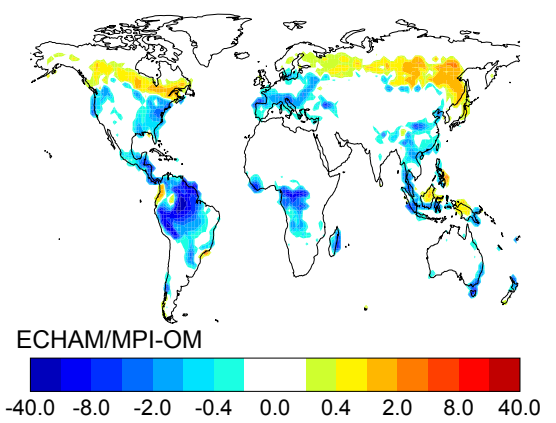

d) soil moisture

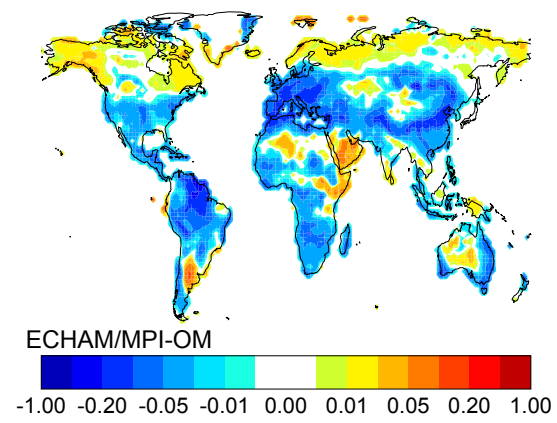

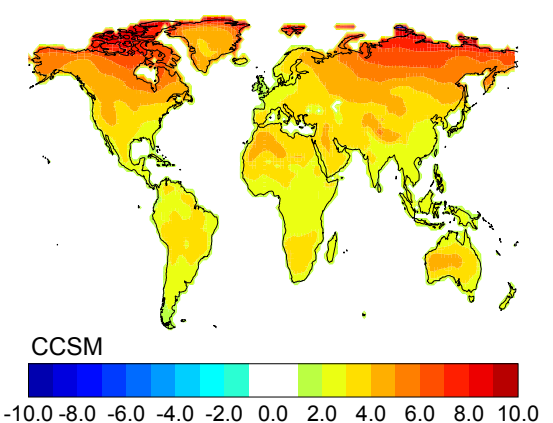
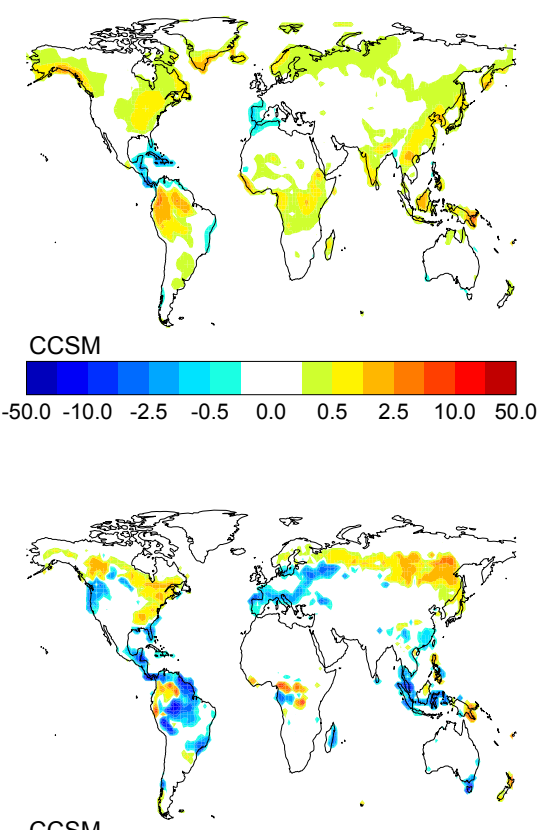

CCSM
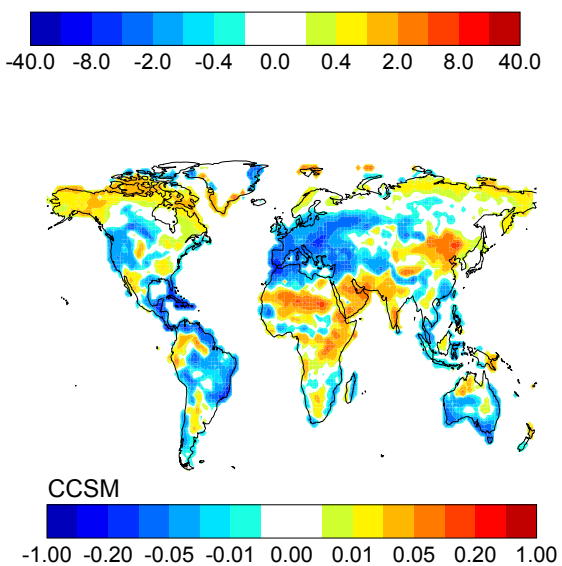

Fig. 5. Changes in climate parameters (annual mean) averaged over the period 2075-2099 compared to the control simulation with constant climate. Left side: ECHAM/MPI-OM (AB-45-E1 minus AB-CLIM-45), right side: CCSM (AB-45-C1 minus AB-CLIM-45). 1st row: temperature in [ $\mathrm{deg} \mathrm{C}$; 2 nd row: precipitation in $\left[\mathrm{mm} \mathrm{d}^{-1}\right]$; 3rd row: aboveground biomass $\left[\mathrm{kgC} \mathrm{m}^{-2}\right]$; 4th row: soil moisture [fraction of the plant-available volumetric water content in the top $5 \mathrm{~cm}$ of the soil column]. 
(a) biomass probability of fire occurence
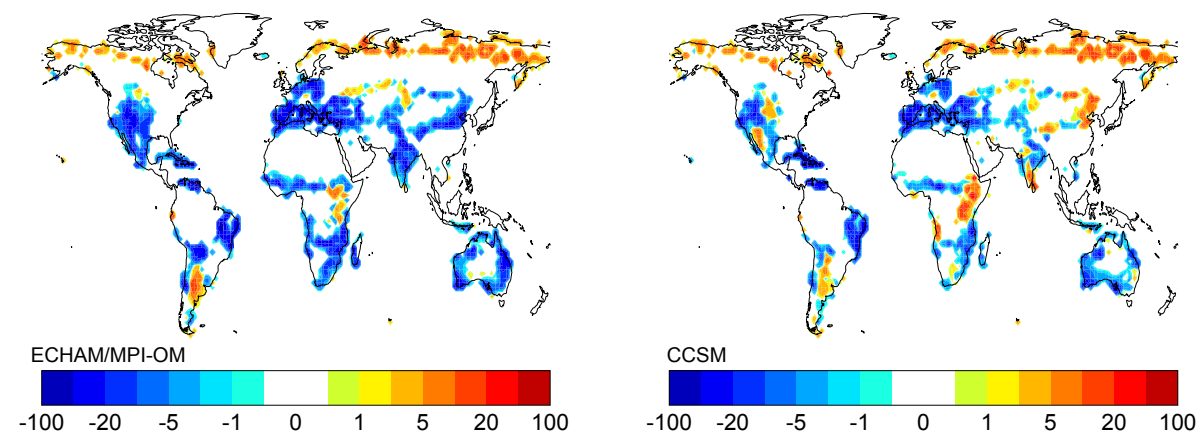

(b) moisture probability of fire occurence
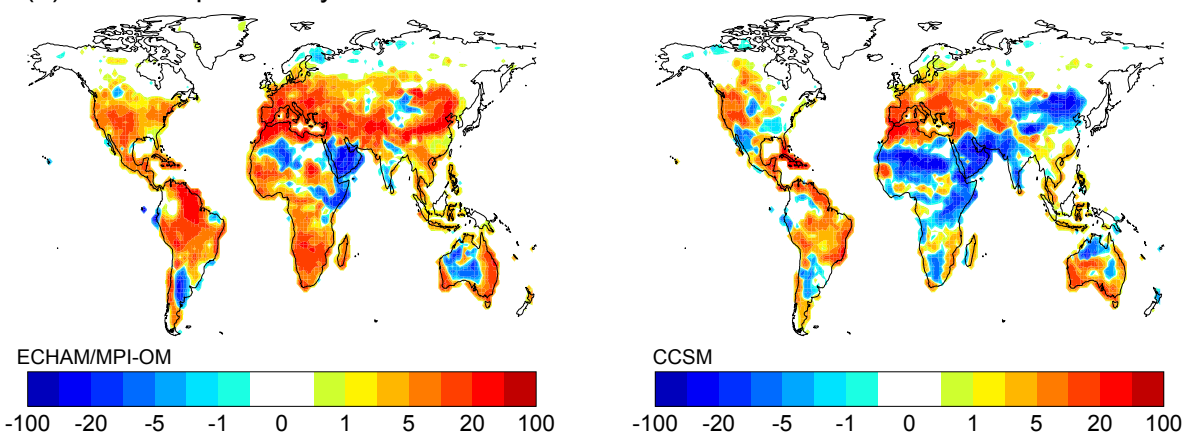

Fig. 6. Change in fire occurence probabilities (annual mean) averaged over the period 2075-2099 compared to the control simulation with constant climate. Left side: ECHAM/MPI-OM (AB-45-E1 minus AB-CLIM-45), right side: CCSM (AB-45-C1 minus AB-CLIM-45). 1st row: biomass probability of fire occurence $[\times 100]$; 2nd row: moisture probability of fire occurence $[\times 100]$.

The annual mean fire emissions changes due to climate at the end of the 21st century (2075-2099) simulated for the different climate projections differed substantially in their spatial distribution (Fig. 4). Globally, the annual mean emissions increased for both climate projections. By the end of the 21st century (average 2075-2099) fire emissions were $66 \%$ higher compared to the control for ECHAM5/MPIOM. The CCSM climate projection led to an increase of $+22 \%$, see also Table 2. Regionally, the response for the two climate projections was largest for Southern Hemisphere South America, central Asia, and Northern Hemisphere Africa (Table 2).

In the fire model applied in this study simulated fires depended directly on probability functions representing the availability of biomass (aboveground biomass), moisture (soil moisture), and ignition (lightning and human ignition) (Kloster et al., 2010). The moisture and biomass probability functions responded to changes in climate. Changes in fire emissions as a response to climate change closely followed in most regions the simulated response in soil moisture and resulting moisture probability for fire occurrence (Figs. 5d and $6 b)$. Reduced soil moisture coincided in many regions with decreased aboveground biomass and thus lower fuel loads (Figs. 5c and 6a). Therefore, changes in simulated fire emissions were a result of changes in moisture and changes in biomass. However, the overall response pattern was dominated by the simulated response in the moisture probabilities. Only in some regions were changes in fire emissions dominated by differences in the aboveground biomass. Southern Europe, for example, experienced a decrease in precipitation rates according to both applied future climate forcings. The lower precipitation rate led to an increase in moisture probability, but also to a decrease in available biomass for burning and thus a decrease in aboveground biomass and fuel load. Overall the decrease in fuel load (biomass probability) prevailed for Southern Europe resulting in lower future fire emissions (Fig. 4).

Large parts of the Northern Hemisphere showed strong spatial coherency in the response of fire to the two climate projections, with increasing future fire emissions, for example, in Northern Europe and decreasing emissions over Southern Europe (Fig. 4). For the boreal regions (Boreal Asia and Boreal North America) the changes in precipitation from the two different climate projections were very similar (Fig. 5b), as were the simulated changes in moisture (Fig. 5d) and biomass (Fig. 5c).

Regions that showed a change in the month of maximum burning had a tendency of shifting the maximum burning later into the year for many regions at mid and high latitudes of the Northern Hemisphere (+2 months, Fig. 7a). In South 
(a) change in month of maximum burning
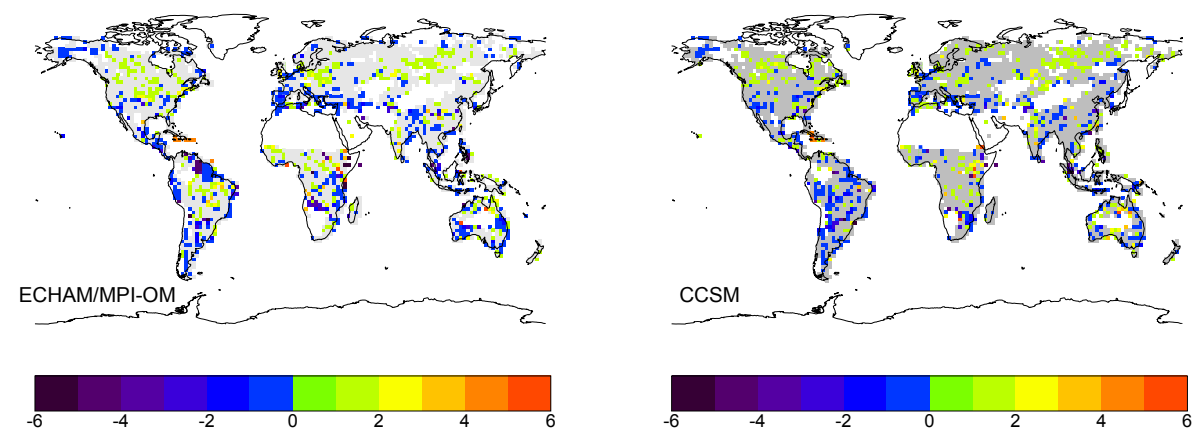

(b) change in fire season length
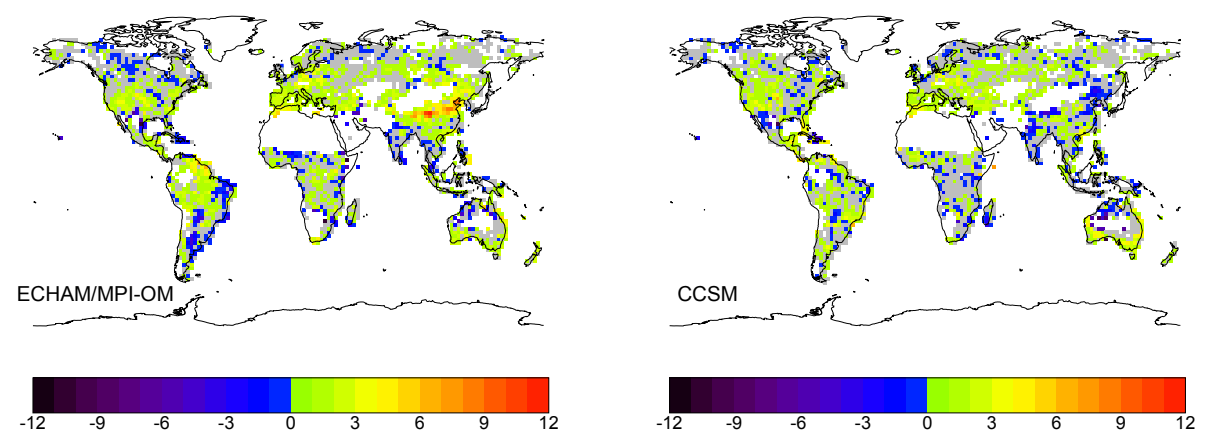

Fig. 7. Changes in fire seasonality averaged over the period 2075-2099 compared to the control simulation with constant climate. Left side: ECHAM/MPI-OM (AB-45-E1 minus AB-CLIM-45), right side: CCSM (AB-45-C1 minus AB-CLIM-45). 1st row: change in month with maximum burning [months]; 2nd row: change in number of months with fire occurence [months].

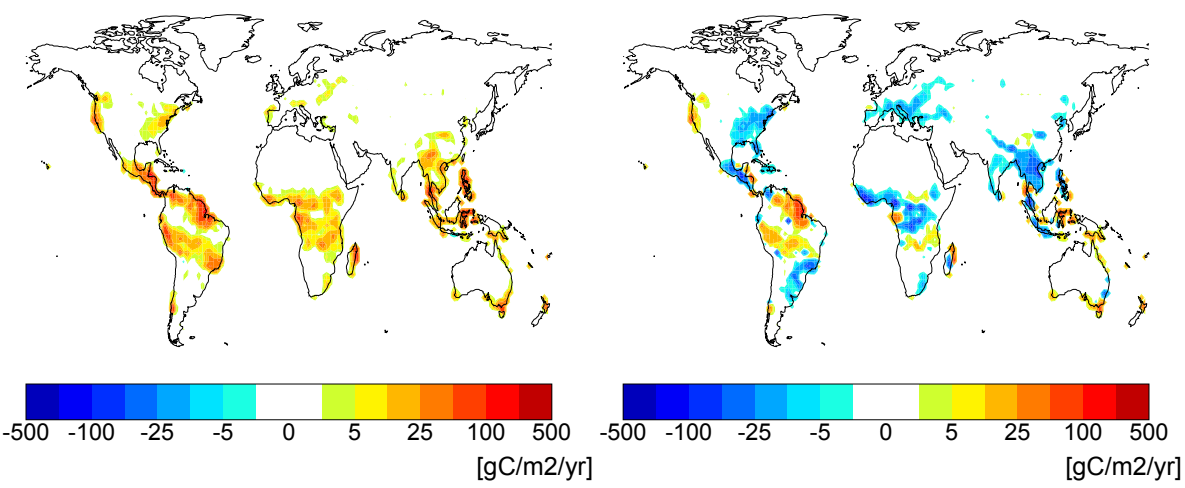

Fig. 8. Change in annual mean fire emissions in $\left[\mathrm{gC} /\left(\mathrm{m}^{2} \mathrm{yr}\right)\right]$ averaged over $2075-2099$ introduced by changes in population density. Simulations with transient varying forcings are compared to a control simulation in which the forcing is kept constant at preindustrial level. Left side: only human ignition considered (AB-HI-45-E1 minus AB-HI-PI-45-E1); right side: human ignition and fire suppression considered (AB-HI-FS-45-E1 minus AB-HI-FS-PI-45-E1).

America, in contrast, the month of maximum burning shifted to earlier periods or remained unchanged. The majority of the grid cells, however, showed no change in the month of maximum burning. The length of the burning season (number of months in which fire emissions occured) extended in some regions (Fig. 7b). This change in the fire regime was especially prominent in Central Asia. Here fire emissions peaked not only in May but also in August and emissions stayed relatively high in between (Fig. 10). Fires were simulated for all months of the year, including December and January, which experienced no burning without changing climate. This increase in fire emissions and the longer burning season was a result of decreasing soil moisture, which was most pronounced for the ECHAM5/MPI-OM climate projection (Fig. 10). At the same time, fuel loads were reduced lowering the biomass probability, which however, was not 

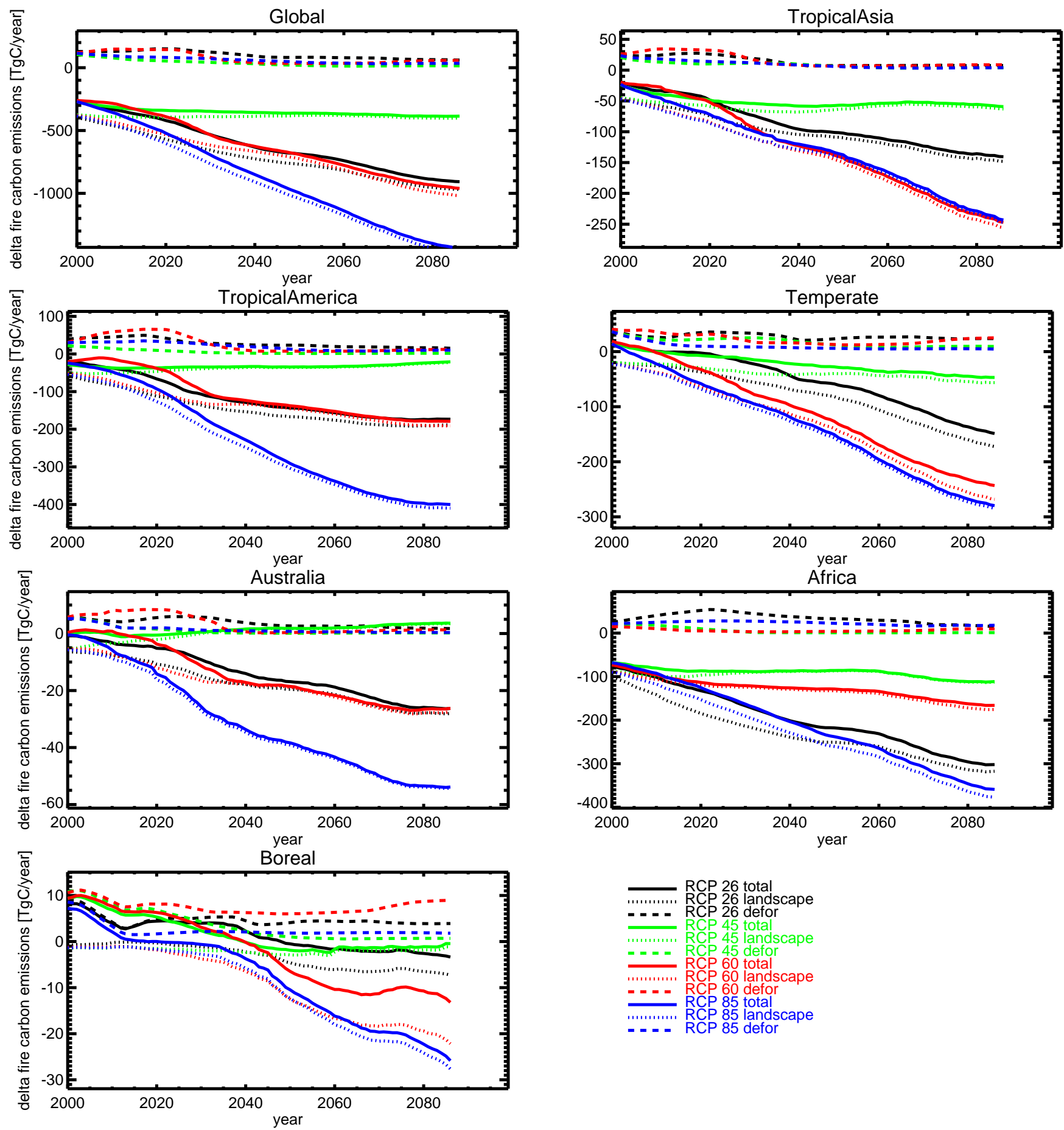

Fig. 9. Change in annual mean landscape, deforestation, and total (landscape plus deforestation) fire emissions in [ $\left.\mathrm{TgC} \mathrm{yr}^{-1}\right]$ introduced by $^{-1}$ different harvest/land cover change projections (RCP 26, 45, 60, 85) for different major world regions. Simulations with transient varying forcings are compared to a control simulation with constant harvest/land cover. The timeseries were smoothed with a $25 \mathrm{yr}$ running mean. Similar to van der Werf et al. (2010) the different regions were composed of BONA and BOAS (Boreal), TENA, EURO, CEAS (Temperate), CEAM, NHSA, and SHSA (Tropical America), MIDE, NHAF, and SHAF (Africa), SEAS and EQAS (Tropical Asia), and AUST for Australia (see also Table 2). 

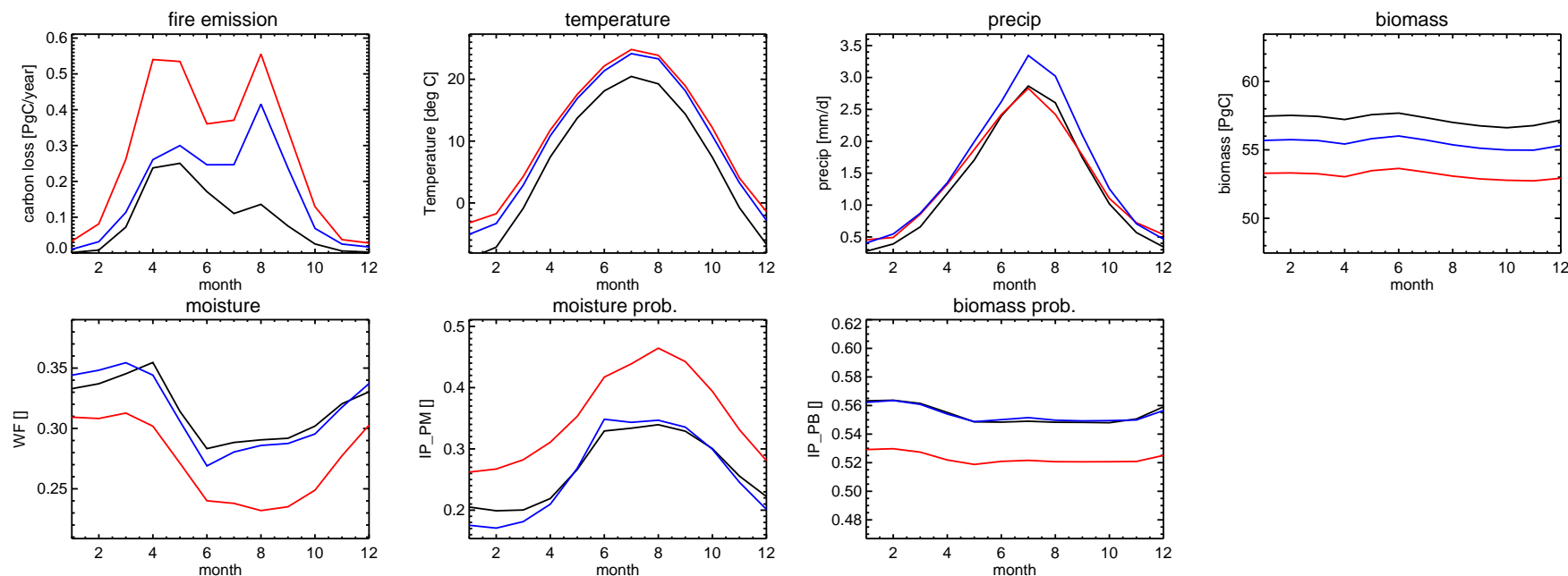

Fig. 10. Central Asia (CEAS): seasonal variation in fire carbon emissions $\left[\mathrm{TgC} \mathrm{yr}^{-1}\right]$, climate parameters (temperature [deg C] and precipitation $\left[\mathrm{mm} \mathrm{d}^{-1}\right]$ ), aboveground biomass $\left[\mathrm{g} \mathrm{C} \mathrm{m}^{-2}\right]$ and moisture and biomass constrained fire occurence probabilities (ip_pb and ip_pm []) averaged over the period 2075-2099. Red: ECHAM/MPI-OM climate forcing; blue: CCSM climate forcing; black: control simulation with constant climate.
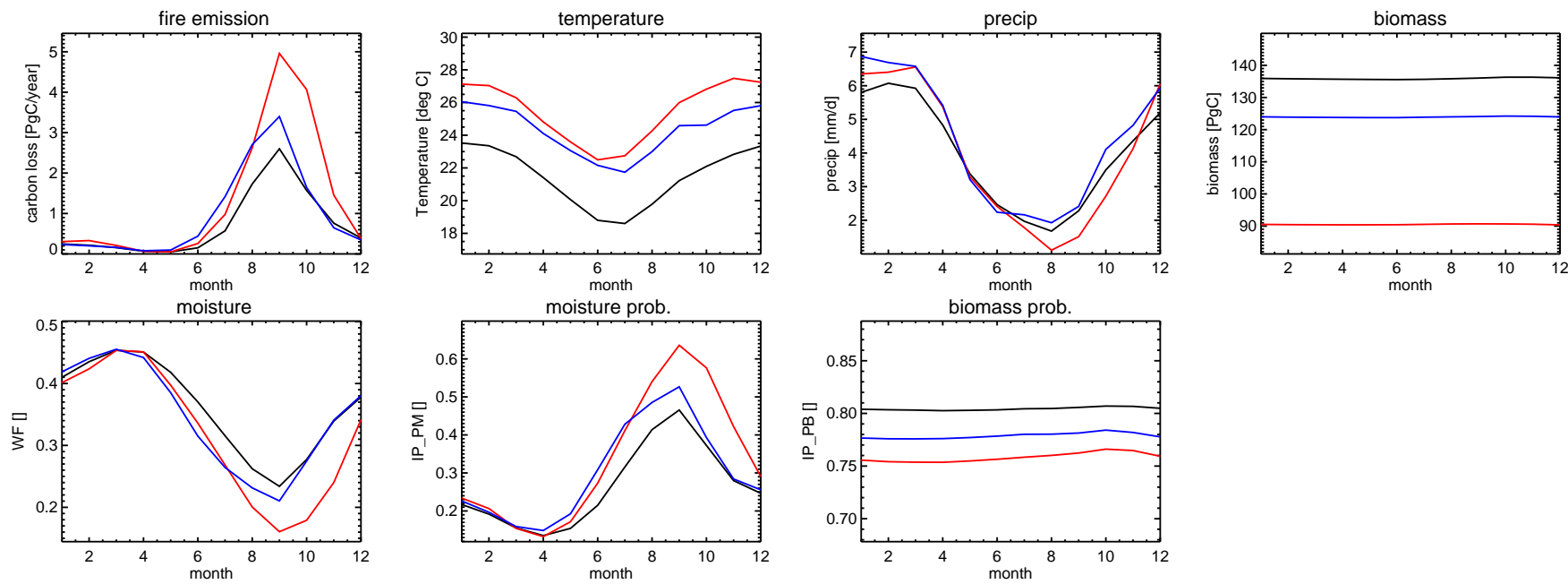

Fig. 11. Similar as Fig. 10 for the region Southern Hemisphere South America (SHSA).

sufficient to outweigh the increase in fire emissions caused by drier fuels.

The difference in the global response of fire emissions to changes in climate was largely explained by differences over South America and Africa. South America and Africa were the continents that contributed the most to the preindustrial global annual fire emissions $(\sim 25 \%$ and $\sim 50 \%$, respectively, Table 2). For South America both future climate forcings led to an increase in fire emissions. However, the response was stronger for the ECHAM5/MPI-OM forcing (+61\% and $+84 \%$ for Northern and Southern Hemisphere South America, respectively) than for the CCSM forc- ing $(+22 \%$ and $+33 \%$, respectively, Table 2$)$. The difference in fire emissions responses for the two climate projections was a result of differences in projected changes in soil moisture (Fig. 5d). The decreases in soil moisture from the ECHAM5/MPI-OM projection resulted in increases in fire carbon emissions for Southern Hemisphere South America not only in September, but also high emissions occured in October and November (Fig. 11). The ECHAM5/MPI-OM climate projections decreased precipitation to almost zero in August averaged over Southern Hemisphere South America. This resulted in lower soil moisture in September and a slow recovery in October and November. The CCSM climate 

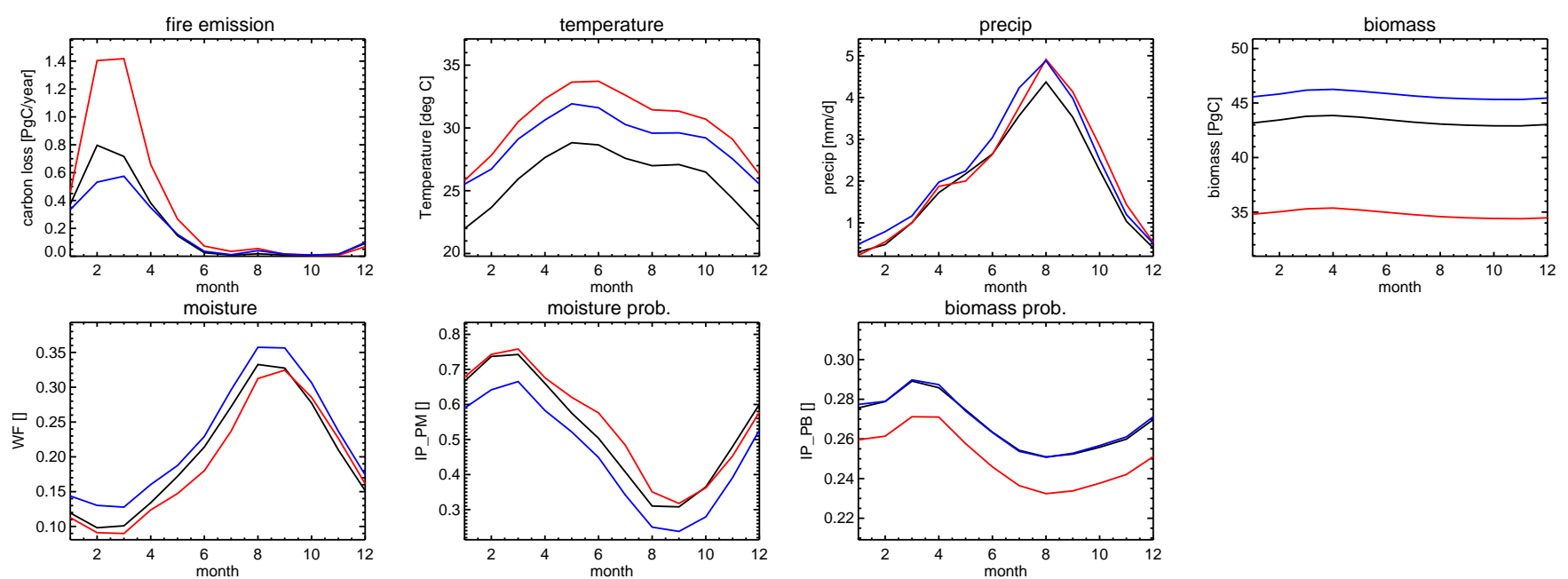

Fig. 12. Similar as Fig. 10 for the region Northern Hemisphere Africa (NHAF).

projections led to a different response. Here the soil moisture was simulated lower in the future for April to September, leading to higher fire emissions in these months at the onset of the fire season.

For Africa fire emissions increased with the ECHAM5/MPI-OM climate projection $(+50 \%)$, while they decreased with CCSM climate projection $(-5 \%)$. Both projections showed an increase in precipitation over Africa (Fig. 5b). However, only the simulation forced with CCSM forcing resulted in an increase in soil moisture (Fig. 5d) over central Africa and thus a decrease in fire emissions. In contrast, the simulation forced with ECHAM5/MPI-OM projection showed a decrease in soil moisture over much of Africa, despite increasing precipitation. The decrease in soil moisture was caused by higher evaporation rates that exceeded the increase in precipitation. Higher evaopration rates were in turn caused by increases in surface temperatures that were stronger in the ECHAM5/MPI-OM projection compared to the CCSM projection (Fig. 5a). While the precipitation change by the two climate models over Africa was comparable, the overall changes in the hydrological cycle defining the soil moisture and thus fire occurrence probability were not. This was also reflected in the seasonal changes (Fig. 12). With the ECHAM5/MPI-OM forcing fire emissions increased for Northern Hemisphere Africa strongly in the burning season and the months with maximum emissions remained February and March. With CCSM climate projections, however, the simulated decrease in fire emissions was most pronounced for these peak months.

\subsection{Response of fire to future changes in population density}

The response of fire emissions to changes in population density is controlled via two counteracting processes in our model. An increase in population leads to an increase in ignition sources as well as to an increase in fire management efforts set in place to suppress fires. In the model, the probability of human ignition increased with increasing population density, while fire suppression rates were highest in densely populated areas (Kloster et al., 2010). Changes in population density were prescribed following Klein Goldewijk (2001) up to the year 2004. For future years (2005 to 2100) population densities were scaled for the SRES world regions following the A1 projection (CIESIN, 2002), for which global total population increases in the future up to the year 2050 and slightly declines afterwards (Fig. 1b).

When only human ignition was considered in the model, global future fire emissions increased until 2050 as a response to globally increasing population density and stayed almost constant thereafter (Fig. 3, HI case). Taking also fire management into account, global fire emission did not change significantly over the course of the 21 st century (Fig. 3; HI-FS case).

When only human ignition was considered fire emissions increased globally by $20 \%$ compared to preindustrial times (Table 2). Regionally (see Fig. 8), increases in fire emission caused by human ignition were largest in central America (a $47 \%$ increase) and Equatorial Asia (a $44 \%$ increase). When fire suppression was included, in some regions fire emissions still increased (Northern Hemisphere South America $(+22 \%)$, Southern Hemisphere South America $(+3 \%)$, boreal North America $(+3 \%)$, Australia $(+14 \%))$. However, globally the increase in fire suppression dominated the response and fire emissions decreased globally by $-6 \%$. 
Decreases were largest in southern East Asia, Europe and the Middle East $(-33,-29$, and $-29 \%$, respectively).

\subsection{Response of fire to future changes in harvest and land use}

The impact of harvest and land use on simulated fire emissions occurs as a result of two different mechanisms. Harvest and changes in land use alter the biomass available for burning and thus emissions from natural landscape fires. In addition, fires are often used as a tool for forest clearing leading to an additional fire source (deforestation fires). For the 20th century we found that globally total fire emissions (landscape and deforestation) decreased as a result of harvest and land use change (Kloster et al., 2010). The simulations presented here showed that this trend generally continues (Fig. 9). Although the response varied considerably between different harvest/land cover change projections (RCP 26, 40, 60, and 85 , respectively).

Globally, total (deforestation and landscape) fire emissions decreased by the largest amount for the RCP 85 projection (averaged over the period 2075-2099 by $-35 \%$, Table 2). The weakest response was simulated in the RCP 45 scenario $(-5 \%)$. RCP 26 and RCP 60 had globally a very similar response $(-21$ and $-22 \%)$.

At a regional scale, RCP 26 and RCP 60 scenarios differed considerable. RCP 26 led to strong decreases in total fire emissions over northern and Southern Hemisphere Africa ( $-33 \%$ compared to $-16 \%$ for RCP 60 ), while for RCP 60 the decrease was strongest over south East and Equatorial Asia ( $-52 \%$ compared to $-30 \%$ for RCP 26 ).

For all the RCP projections deforestation fire emissions were lower during 2075-2099 compared to present day, as a result of decreased land conversion rates (see also Fig. 1c). Although, the RCP projection 26 and 85 peaked in between ( $\sim 2020$ and $\sim 2015$, respectively). Averaged over 2000 2024 deforestation fires emitted globally 134, 64, 145, and $86 \mathrm{Tg} \mathrm{C} \mathrm{yr}^{-1}$ (RCP 26, 45, 60 and 85, respectively). This was reduced for the period 2075-2099 to 60, 15, 58, and $35 \mathrm{Tg} \mathrm{C} \mathrm{yr}^{-1}$, respectively. Thereby, the burning fraction of the biomass that was left on site after land use conversion remained relatively constant over time (between 33 to $42 \%$ ).

The different magnitudes with which landscape fire emissions decreased in the single RCPs $(-20,-5,-21,-34 \%$ for RCP 26, 45, 60, 85, respectively) was partly reflected in the different projections for wood harvest rates that were $0.77,0.78,1.51$, and $1.83 \mathrm{Pg} \mathrm{Cyr}^{-1}$ on average for the timeperiod 1850-2100 for the scenarios RCP 26, 45, 60 and 85 , respectively. Harvest led to a reduction of biomass available for burning, which overall reduced natural landscape emissions. However, the response varied considerably on regional scale for the different harvest and land use change projections (Fig. 9).

Note here, that Lawrence et al. (2011a) found that the carbon harvest rates in our model for the RCP 60 and RCP 85 were higher than what was intended to be prescribed from the wood harvest areas given by the harmonized RCP projections (Hurtt, 2009). The simulated wood harvest carbon flux for RCP 60 and RCP 85 were $\sim 5$ and $8 \mathrm{Pg} \mathrm{Cyr}^{-1}$ in 2100, respectively. The Global Land Model (GLM, Hurtt, 2009), which harmonized the RCP projections for the usage in the CMIP5 process (Taylor et al., 2009), reported harvest carbon fluxes which were substantially lower for $2100(\sim 2$ and $3 \mathrm{Pg}$ $\mathrm{C} \mathrm{yr}^{-1}$, respectively). The differences were a result of different assumptions on logging techniques and secondary tree growth in the different RCPs, which will have to be further investigated. Lower wood harvest rates, might lead to a less pronounced decrease in landscape fire emissions caused by harvest/land use as simulated here.

\section{Discussion and conclusions}

We applied a global land carbon model (CLM-CN) that interactively simulated landscape fire carbon emissions to investigate the response of future fires to projected changes in climate, population density, and harvest/land cover change during the 21 st century. A previous study showed that the model captured the large scale contemporary observed fire patterns as well as observed trends in fire emissions during the 20th century, leading to some confidence that the model includes parameterizations that represent the sensitivity of fire emissions to important climate and land cover drivers.

We tested the response of future fire emissions to a range of future forcing projections and found that in the model:

- Fire emissions increased as a response to future climate change. For this analyses we applied future climate projections from two different climate models (CCSM and ECHAM5/MPI-OM), both following the SRES A1B scenario. Use of the ECHAM5/MPI-OM climate projection to force CLM-CN resulted in a considerable increase in fire emissions globally (+66\% in 2075-2099 compared to the control). Fire emissions increased less when we used CCSM climate projections $(+22 \%)$. In most regions changes in fire emissions were caused by primarily changes in the length and intensity of the dry season, with many regions showing increases in the drought stress during the dry season. Climate-induced changes in fuel availability also had effect on fire emissions, with reduced levels of net primary production and fuel loads limiting fire emissions in some regions.

- Fire emissions increased globally as a response to increases in future population densities (SRES A1B) when only the impact on human ignition probability was taken into account. Fire emissions remained almost constant globally as a response to changing population density in the future when fire suppression and human ignition processes were included. In this case emissions 
increased in South America, Australia and boreal North America but decreased in all other regions.

- Fire emissions decreased as a response to future projections of harvest/land cover change. In all future projections harvest/land cover change reduced available fuel load and consequently natural fire emissions. The decrease in total (natural and deforestation) fire emissions was weakest $(-5 \%)$ in the RCP45 and strongest $(-35 \%)$ in the RCP85 projections averaged over the period 2075-2099.

- Overall fire emissions increased in the future assuming that harvest/land cover change will follow the RCP 45 trajectory and population changes will impact fire ignition and suppression in the case of the CCSM climate forcing by $17 \%$ and the ECHAM5/MPI-OM climate forcing by $62 \%$ compared to present day.

Increasing future fire emissions have been reported in earlier work based on global fire models with varying levels of complexity (Scholze et al., 2006; Krawchuk et al., 2009; Pechony and Shindell, 2010). However, regionally the response pattern differed substantially in these global studies as well as in regional studies that focused on the impact of climate change on fires for specific regions (mostly North America, e.g. Spracklen et al., 2009; Euskirchen et al., 2009; Amiro et al., 2009; Flannigan et al., 2000). Flannigan et al. (2009) analysed around 40 published studies that investigated the implications of changing climate for global wildland fire on different scales and with models of different complexity. They concluded that fire activity will generally increase in the future, but there will be regions with no changes and regions with decreases. For the boreal and temperate regions they found an overall consensus that the fire season will be lengthened in the future, which is in line with more recent studies (e.g. Balshi et al., 2009; Spracklen et al., 2009; Wotton et al., 2010; Westerling et al., 2011), and was also reproduced in our results. Pechony and Shindell (2010) investigated the impact of individual forcings on fire activity and came to similar conclusions as we did: the trend in future fire activity is largely driven by changes in climate and the direct human impact through ignition and fire management becomes less relevant. Decreasing fuel loads induced by land use change led in both studies to a decrease in landscape fire activity.

Differences in projected fire emissions partly reflected differences in the fire models, which span a range of empirical and prognostic approaches. However, they also result from the use of different projections of future climate in individual studies. Our simulations showed that climate projections for the 21 st century from two different global climate models that both applied the same SRES A1B scenario resulted in projected fire emission trends that showed considerable difference for example in Africa, between a slight decreasing trend up to a moderate increase in future fire emissions.
In a recent study Pechony and Shindell (2010) showed that the same climate model but different SRES projections resulted in broadly similar spatial patterns of fire emissions but with different magnitudes corresponding to the degree of climate warming. Similar findings were reported by Scholze et al. (2006). These differences in climate projections reflect the range of possible future climate developments and applied in fire models the range of possible climate driven changes in fire emissions. In light of this variability between climate models, an intercomparison of the sensitivity of fire models to future climate change would require the use of the same climate projection. This could be done, for example by embedding multiple fire emissions models within the same vegetation-carbon model. Our study suggests, in addition, that changes in population and harvest and land use will also have a considerable influence on the trajectory of fire emissions during the 21 st century. Projections of these factors and their influence on fire emissions vary considerably depending on future scenario assumptions of socio-economic development and the implementation of these land use scenarios within Earth System Models.

Although our model captures some of the temporal and spatial variability of contemporary fires (Kloster et al., 2010) there are a number of processes in the model that are based on a rather incomplete understanding of human-fire interactions (Pechony and Shindell, 2010). Human-fire interactions are to a large part socio-economically controlled with varying fire management practices ranging from active fire suppression efforts, typically applied in regions were high property values are at risk, to the use of fires for conversion of vegetation to agriculture (Bowman et al., 2009). These fire management practices in turn depend on fuel characteristics that will change with a changing climate (Flannigan et al., 2009). This makes it particularly difficult to take changing fire management practices into account for future fire emission predictions. Comprehensive information on past fire activity, e.g. reconstructed from charcoal sediments (Power et al., 2010), explored in more detail in conjunction with reconstructed land use change pattern will hopefully allow for improvements in our current understanding of human-fire interactions.

Another parameter we did not consider in the fire model is the impact of climate change on lightning activity and subsequent effects on ignition. Price and Rind (1994) explored the impact of climate change on lightning-caused fires and concluded for North America that the burned area will increase by $78 \%$ as a response to increased lightning activity caused by a doubling of atmospheric $\mathrm{CO}_{2}$ concentration. To our knowledge there is no estimate how increased lightning activity affects fire emissions on a global scale. Such an assessment, however, will have to take into account the number of human ignitions and fire management efforts as well.

Due to computational limitations we were only able to apply climate projections from two different climate models using one future fossil fuel emission scenario, which, however, 
showed large differences in the simulated future fire emissions. In the future it will be desirable to apply a larger set of future climate model projections. CMIP5 (Taylor et al., 2009) will form here an ideal consistent basis. This will also allow to explore future fire emissions for different emission scenario projections (different RCPs). Pechony and Shindell (2010) investigated the response of future fire activity for three different SRES marker scenarios applied to the GISS climate model. They found that future fire activity increases by 15,19 , and $35 \%$ in 2100 compared to preindustrial times for the scenarios A1, A1B, and A2, respectively. This range is smaller compared to the difference we found in future fire activity when two different climate models with the same emission scenario were used.

The simulation presented here showed that climate also had a substantial indirect control on future fire carbon emission through the alteration of fuel availability partly caused by changes in fire activity itself. A coupled vegetationcarbon model as used in this study allowed us to account for this, in contrast to other studies that were solely based on statistical relationships (Krawchuk et al., 2009) or did prescribe biomass density (Pechony and Shindell, 2010).

We did not include peat fire carbon emissions in this study. While this excludes a large emission source especially from the tropical peat regions under present day conditions (e.g. Page et al., 2002) it also does not account for possible future permafrost thawing in the boreal regions that might expose large amount of soil organic carbon to burning (Turetsky et al., 2011). Peat fire emission modeling will require an adequate parameterization of carbon accumulation in peat areas. This is currently under development for several global carbon vegetation models (e.g. Wania et al., 2009; Kleinen et al., 2012) and might form the basis for future studies.

Increasing fire activity as a response to climate change will itself lead to changes in climate (Randerson et al., 2006; Bowman et al., 2009). To understand this fire-climate feedback we will have to improve our current ability to represent fires as an active climate dependent component of the Earth System. A fire model as presented in this study forms one step towards this direction.

Acknowledgements. This work was supported by the US National Science Foundation (NSF ATM-0628637, NSF AGS-1048890). For computational support the authors acknowledge NSF and the National Center for Atmospheric Research (NCAR). NCAR is sponsored by the NSF.

The service charges for this open access publication have been covered by the Max Planck Society.

Edited by: K. Thonicke

\section{References}

Amiro, B., Cantin, A., Flannigan, M., and de Groot, W.: Future emissions from Canadian boreal forest fires, Can. J. Forest Res., 39, 383-395, doi:10.1139/X08-154, 2009.

Arora, V. K. and Boer, G. J.: Fire as an interactive component of dynamic vegetation models, J. Geophys. Res., 110, G02008, doi:10.1029/2005JG000042, 2005.

Balshi, M. S., McGuire, A. D., Duffy, P., Flannigan, M., Kirklighter, D. W., and Melilli, J.: Vulnerability of carbon storage in North American boreal forests to wildfires during the 21st century, Global Change Biology, 15, 1491-1510, 2009.

Boden, T., Marland, G., and Andres, B.: Global $\mathrm{CO}_{2}$ Emissions from Fossil-Fuel Burning, Cement Manufacture, and Gas Flaring: 1751-2008, available at: http://cdiac.ornl.gov/ftp/ndp030/ global.1751_2008.ems (last access: July 2011), 2009.

Bowman, D. M. J. S., Balch, J. K., Artaxo, P., Bond, W. J., Carlson, J. M., Cochrane, M. A., D’Antonio, C. M., DeFries, R., Doyle, J. C., Harrison, S. P., Johnston, F. H., Keeley, J. E., Krwchuk, M. A., Kull, C. A., Marston, J. B., Mortiz, M. A., Prentice, I. C., Roos, C. I., Scott, A. C., Swetnam, T. W., van der Werf, G. R., and Pyne, S. J.: Fire in the Earth System, Science, 324, 481, doi:10.1126/science.1163886, 2009.

CIESIN: Country-level Population and Downscaled Projections based on the A1 Scenario, 1990-2100, [digital version]., Center for International Earth Science Information Network, Columbia University, Palisades, NY, available at: http://www.ciesin. columbia.edu/datasets/downscaled (last access: June 2011), 2002.

Euskirchen, E. S., McGuire, A. D., Rupp, T. S., Chapin, F. S., and Walsh, J. E.: Projected changes in atmospheric heating due to changes in fire disturbance and the snow season in the western Arctic, 2003-2100, J. Geophys. Res., 114, 1-15, doi:10.1029/2009JG001095, 2009.

Flannigan, M., Stocks, B., and Wotton, B.: Climate change and forest fires, Sci. total Environ., 262, 221-9, 2000.

Flannigan, M. D., Krawchuk, M. A., de Groot, W. J., Wotton, B. M., and Gowman, L. M.: Implications of changing climate for global wildland fire, International Journal of Wildland Fire, 18, 483, doi:10.1071/WF08187, 2009.

Friedlingstein, P., Cox, P., Betts, R., Bopp, L., von Bloh, W., Brovkin, V., Cadule, P., Doney, S., Eby, M., Fung, I., Bala, G., John, J., Jones, C., Joos, F., Kato, T., Kawamiya, M., Knorr, W., Lindsay, K., Matthews, H. D., Raddatz, T., Rayner, P., Reick, C., Roeckner, E., Schnitzler, K.-G., Schnur, R., Strassmann, K., Weaver, a. J., Yoshikawa, C., and Zeng, N.: Climate-Carbon Cycle Feedback Analysis: Results from the C4MIP Model Intercomparison, J. Climate, 19, 3337-3353, doi:10.1175/JCLI3800.1, 2006.

Gillett, N. P., Weaver, A. J., Zwiers, F. W., and Flannigan, M. D.: Detecting the effect of climate change on Canadian forest fires, Geophys. Res. Lett., 31, L18211, doi:10.1029/2004GL020876, 2004.

Houghton, R. A., Hobbie, J. E., Melillo, J. M., Morre, B., Peterson, B. J., Shaver, G. R., and Woodwell, G. M.: Changes in the carbon content of terrestial biota and soils between 1860 and $1980-\mathrm{A}$ net release of $\mathrm{CO}_{2}$ to the atmosphere, Ecol. Monogr., 53, 235262, 1983.

Hurtt, G.: Harmonisation of global land-use scenarios for the period 1500-2100 for IPCC-AR5, IGBP iLEAPS Newsletter, 7, 6-8, 
2009.

Hurtt, G. C., Frolking, S., Fearon, M. G., Moore, B., Shevliakova, E., Malyshev, S., Pacala, S. W., and Houghton, R. A.: The underpinnings of land-use history: three centuries of global gridded land-use transitions, wood-harvest activity, and resulting secondary lands, Glob. Change Biol., 12, 1208-1229, doi:10.1111/j.1365-2486.2006.01150.x, 2006.

Kleinen, T., Brovkin, V., and Schuldt, R. J.: A dynamic model of wetland extent and peat accumulation: results for the Holocene, Biogeosciences, 9, 235-248, doi:10.5194/bg-9-235-2012, 2012.

Klein Goldewijk, K.: Estimating global land use change over the past 300 years: The HYDE Database, Global Biogeochem. Cy., 15, 417-433, 2001.

Kloster, S., Mahowald, N. M., Randerson, J. T., Thornton, P. E., Hoffman, F. M., Levis, S., Lawrence, P. J., Feddema, J. J., Oleson, K. W., and Lawrence, D. M.: Fire dynamics during the 20th century simulated by the Community Land Model, Biogeosciences, 7, 1877-1902, doi:10.5194/bg-7-1877-2010, 2010.

Krawchuk, M., Moritz, M., Parisien, M., Dorn, J. V., and Hayhoe, K.: Global pyrogeography: the current and future distribution of wildfire, PloS One, 4, doi:10.1371/journal.pone.0005102, 2009.

Lamarque, J. F., Kiehl, J., Brasseur, G., Butler, T., Cameron-Smith, P., Collins, W. D., Collins, W. J., Granier, C., Hauglustaine, D., Hess, P., Holland, E., Horowitz, L., Lawrence, M., McKenna, D., Merilees, P., Prather, M., Rasch, P., Rotman, D., Shindell, D., and Thornton, P.: Assessing future nitrogen deposition and carbon cycle feedbacks using a multi-model approach: Analysis of nitrogen deposition, J. Geophys. Res., 110, D19303, doi:10.1029/2005JD005825, 2005.

Lawrence, P., Feddema, J., Bonan, G., Meehl, G., O’Neill, B., Levis, S., Lawrence, D., Oleson, K., Kluzek, E., Lindsay, K., and Thornton, P.: Simulating the biogeochemical and biogeophysical impacts of the transient land cover change and wood harvest in the Community Climate System Model (CCSM4) from 1850 to 2100, J. Climate, accepted, 2011a.

Lawrence, D. M., Oleson, K. W., Flanner, M. G., Thornton, P. E., Swenson, S. C., Lawrence, P. J., Zeng, X., Yang, Z.-L., Levis, S., Sakaguchi, K., Bonan, G. B., and Slater, A. G.: Parameterization improvements and functional and structural advances in Version 4 of the Community Land Model, J. Adv. Model. Earth Syst., 3, 1-27, doi:10.1029/2011MS000045, 2011b.

LIS/OTD: Lightning Imaging Sensor/Optical Transient Detector: NASA LIS/OTD Science Team (Principal Investigator, Dr. Hugh J. Christian, NASA/Marshall Space Flight Center), available from the Global Hydrology Resource Center, available at: http: //ghrc.msfc.nasa.gov, latest access 2011.

Marlon, J. R., Bartlein, P. J., Walsh, M. K., Harrison, S. P., Brown, K. J., Edwards, M. E., Higuera, P. E., Power, M. J., Anderson, R. S., Briles, C., Brunelle, A., Carcaillet, C., Daniels, M., Hu, F. S., Lavoie, M., Long, C., Minckley, T., Richard, P. J. H., Scott, A. C., Shafer, D. S., Tinner, W., Umbanhowar, C. E., and Whitlock, C.: Wildfire responses to abrupt climate change in North America, P. Natl. Acad. Sci. USA, 106, 2519 24, doi:10.1073/pnas.0808212106, 2009.

Meehl, G., Washington, W., Santer, B., Collins W. D., Arblaster, J. M., Hu, A., Lawrence, D. M., Teng, H., Buja, L. E., and Strand, W. G.: Climate change projections for the twenty-first century and climate change commitment in the CCSM3, J. Climate, 19, 2597-2616, 2006.
Meehl, G., Stocker, T., Collins, W., Friedlingstein, P., Gaye, A., Gregory, J., Kitoh, A., Knutti, R., Noda, J. M. A., Raper, S., Watterson, I., Weaver, A., and Zhao, Z.-C.: Global Climate Projections, in: Climate Change 2007: The Physical Science Basis. Contribution of Working Group I to the Fourth Assessment Report on the Intergovernmental Panel on Climate Change, edited by: Solomon, S., Wuin, D., Manning, M., Chen, Z., Marquis, M., Averyt, K., Tignor, M., and Miller, H., Cambridge University Press, Cambrige, United Kingdom and New York, NY, USA, 2007.

Moss, R. H., Edmonds, J. A., Hibbard, K. A., Manning, M. R., Rose, S. K., van Vuuren, D. P., Carter, T. R., Emori, S., Kainuma, M., Kram, T., Meehl, G. A., Mitchell, J. F. B., Nakicenovix, N., Riahi, K., Smith, S. .J., Stouffer, R. J., Thomson, A. M., Weyant, J. P., and Wilbanks, T. J.: The next generation of scenarios for climate change research and assessment., Nature, 463, 747-56, doi:10.1038/nature08823, 2010.

Nakicenovic, N., Davidson, O., Davis, G., Gruebler, A., Kram, T., La Rovere, E. L., Metz, B., Morita, T., Pepper, W., Pitcher, H., Sankovski, A., Shukla, P., Swart, R., Watson, R., and Dadi, Z.: Special Report on Emissions Scenarios, in: Contribution to the Intergovernmental Panel on Climate Change, Cambridge University Press, Cambridge, UK, 2000.

Oleson, K. W., Bonan, G. B., Feddema, J., Vertenstein, M., and Grimmong, C. S. B.: An urban paramterization for a global climate model. 1. Formulation and evaluation of two cities, J. Appl. Meteorol. Clim., 47, 1038-1060, 2008.

Page, S. E., Siegert, F., Rieley, J. O., Boehm, H.-D. V., Jayak, A., and Limink, S.: The amount of carbon released from peat and forest fires in Indonesia during 1997, Nature, 1, 61-65, 2002.

Pechony, O. and Shindell, D. T.: Fire parameterization on a global scale, J. Geophys. Res., 114, D16115, doi:10.1029/2009JD011927, 2009.

Pechony, O. and Shindell, D. T.: Driving forces of global wildfires over the past millennium and the forthcoming century, P. Natl Acad. Sci., 107, 19167-19170, doi:10.1073/pnas.1003669107, 2010.

Pierce, E. T.: Latitudinal variation of lightning parameters, J. Appl. Meteorol., 9, 164-165, 1969.

Power, M., Marlon, J., Bartlein, P., and Harrison, S.: Fire history and the Global Charcoal Database: A new tool for hypothesis testing and data exploration, Palaeogeogr. Palaeoclimatol., 291, 52-59, doi:10.1016/j.palaeo.2009.09.014, 2010.

Price, C. and Rind, D.: The impact of $2 \mathrm{X} \mathrm{CO}_{2}$ Climate on lightningcaused flashes, J. Climate, 7, 1484-1494, 1994.

Qian, T., Dai, A., Trenberth, K. E., and Oleson, K. W.: Simulation of global land surface conditions from 1948 to 2004 Part I: Forcing data and evaluations, J. Hydrometeorol., 7, 953, doi:10.1175/JHM540.1, 2006.

Randerson, J. T., Liu, H., Flanner, M. G., Chambers, S. D., Jin, Y., Hess, P. G., Pfister, G., Mack, M. C., Treseder, K. K., Welp, L. R., Chapin, F. S., Harden, J. W., Goulden, M. L., Lyons, E., Neff, J. C., Schuur, E. A. G., and Zender, C. S.: The impact of boreal forest fire on climate warming, Science, 314, 1130-1132, doi:10.1126/science.1132075, 2006.

Randerson, J. T., Hoffman, F. M., Thornton, P. E., Mahowald, N. M., Lindsay, K., Lee, Y.-H., Nevison, C. D., Doney, S. C., Bonan, G., Stoeckli, R., Covey, C., Running, S. W., and Fung, I. Y.: Systematic assessment of terrestial biogeochemistry in cou- 
pled climate-carbon models, Glob. Change Biol., 15, 2462-2484, doi:10.1111/j.1365-2486.2009.01912.x, 2009.

Roeckner, E., Brasseur, G., Giorgetta, M., Jacob, D., Jungclaus, J., Reick, C., and Sillmann, J.: Climate Projections for the 21st Century, in: Internal Report, p. 28, Max Planck Institut fuer Meteorologie, available at: http://www.mpimet.mpg.de/fileadmin/ grafik/presse/ClimateProjections2006.pdf, 2006.

Scholze, M., Knorr, W., Arnell, N. W., and Prentice, I. C.: A climate-change risk analysis for world ecosystems, P. Natl. Acad. Sci. USA, 103, 13116-13120, doi:10.1073/pnas.0601816103, 2006.

Seiler, W. and Crutzen, J.: Estimates of the gross and net fluxes of carbon between the biosphere and atmosphere from biomass burning, Clim. Change, 2, 207-247, doi:10.1007/BF00137988, 1980.

Soja, A., Tchebakova, N., French, N., Flannigan, M., Shugart, H., Stocks, B., Sukhinin, A., Parfenova, E., Chapiniii, F., and Stackhousejr, P.: Climate-induced boreal forest change: Predictions versus current observations, Global Planet. Change, 56, 274296, doi:10.1016/j.gloplacha.2006.07.028, 2007.

Spracklen, D. V., Mickley, L. J., Logan, J. A., Hudman, R. C., Yevich, R., Flannigan, M. D., and Westerling, A. L.: Impacts of climate change from 2000 to 2050 on wildfire activity and carbonaceous aerosol concentrations in the western United States, J. Geophys. Res., 114, 1-17, doi:10.1029/2008JD010966, 2009.

Stocks, B. J., Mason, J. A., Todd, J. B., Bosch, E. M., Wotton, B. M., Amiro, B. D., Flannigan, M. D., Hirsch, K. G., Logan, K. A., Martell, L. D., and Skinner, W. R.: Large forest fires in Canada, 1959-1997, J. Geophys. Res., 108, D18149, doi:10.1029/2001JD000484, 2003.

Stoeckli, R., Lawrence, D. M., Niu, G.-Y., Oleson, K. W., Thornton, P. E., Yang, Z.-L., Bonan, G. B., Denning, A. S., and Running, S. W.: The use of Fluxnet in the Community Land Model development, J. Geophys. Res., 113, G01025, doi:10.1029/2007JG000562, 2008.

Taylor, K., Stouffer, R., and Meehl, G.: A Summary of the CMIP5 Experiment Design, available at: http://cmip-pcmdi.llnl.gov/ cmip5/docs/Taylor_CMIP5_design.pdf (last access: July 2011), 2009.

Theobald, M. T. and Romme, W. H.: Expansion of the US wildland-urban interface, Landsc. Urban Plan., 83, 340-354, doi:10.1016/j.landurbplan.2007.06.002, 2007.

Thonicke, K., Venevsky, S., and Sitch, S.: The role of fire disturbance for global vegetation dynamics : coupling fire into a dynamic global vegetation model, Ecology, 661-677, 2001.
Thornton, P. E., Lamarque, J. F., Rosenbloom, N. A., and Mahowald, N. M.: Influence of carbon-nitrogen cycle coupling on land model response to $\mathrm{CO}_{2}$ fertilization and climate variability, Global Biogeochem. Cy., 21, GB4018, doi:1029/2006GB002868, 2007.

Thornton, P. E., Doney, S. C., Lindsay, K., Moore, J. K., Mahowald, N., Randerson, J. T., Fung, I., Lamarque, J.-F., Feddema, J. J., and Lee, Y.-H.: Carbon-nitrogen interactions regulate climate-carbon cycle feedbacks: results from an atmosphereocean general circulation model, Biogeosciences, 6, 2099-2120, doi:10.5194/bg-6-2099-2009, 2009.

Turetsky, M. R., Kane, E. S., Harden, J. W., Ottmar, R. D., Manies, K. L., Hoy, E., and Kasischke, E. S.: Recent acceleration of biomass burning and carbon losses in Alaskan forests and peatlands, Nature Geosci., 4, 27-31, doi:10.1038/ngeo1027, 2011.

van der Werf, G. R., Randerson, J. T., Giglio, L., Collatz, G. J., Kasibhatla, P. S., and Arellano Jr., A. F.: Interannual variability in global biomass burning emissions from 1997 to 2004, Atmos. Chem. Phys., 6, 3423-3441, doi:10.5194/acp-6-3423-2006, 2006.

van der Werf, G. R., Randerson, J. T., Giglio, L., Collatz, G. J., Mu, M., Kasibhatla, P. S., Morton, D. C., DeFries, R. S., Jin, Y., and van Leeuwen, T. T.: Global fire emissions and the contribution of deforestation, savanna, forest, agricultural, and peat fires (19972009), Atmos. Chem. Phys., 10, 11707-11735, doi:10.5194/acp10-11707-2010, 2010.

Venevsky, S., Thonicke, K., Sitch, S., and Cramer, W.: Simulating fire regimes in human-dominated ecosystems: Iberian Peninsula case study, Global Change Biology, 8, 984-998, 2002.

Wania, R., Ross, I., and Prentice, I. C.: Integrating peatlands and permafrost into a dynamic global vegetation model: 1. Evaluation and sensitivity of physical land surface processes, Global Biogeochem. Cy., 30, GB3014, doi:10.1029/2008GB003412, 2009.

Westerling, A. L., Hidalgo, H. G., Cayan, D. R., and Swetnam, T. W.: Warming and earlier spring increase western U.S. forest wildfire activity., Science (New York, N.Y.), 313, 940-943, doi:10.1126/science.1128834, 2006.

Westerling, A. L., Turner, M. G., Smithwick, E. A. H., Romme, W. H., and Ryan, M. G.: Continued warming could transform Greater Yellowstone fire regimes by the mid-21st century, Proceedings of the National Academy of Sciences, 1, 6, 2011.

Wotton, B. M., Nock, C. A., and Flannigan, M. D.: Forest Fire occurence and climate change in Canada, International Journal of Wildlandfire, 19, 253, 2010. 